MONIKA NoVieLLO

Uniwersytet Pedagogiczny w Krakowie, Polska - Pedagogical University of Cracow, Poland

\title{
Projekt rewitalizacji dzielnicy Bagnoli jako czynnik wzrostu gospodarczego Neapolu
}

\section{Revitalisation of the Bagnoli District as a Factor of Economic Growth in Naples}

Streszczenie: W artykule omówiono projekt rewitalizacji poprzemysłowej dzielnicy Neapolu - Bagnoli, która leży w strategicznej lokalizacji na wybrzeżu Zatoki Pozzuoli. Autorka nawiązuje do historii przemysłu na tym obszarze - od jego prężnego rozwoju w okresie powojennym, przez kryzys lat 70., po całkowite zamknięcie fabryk w 1991 r. Od czasu zamknięcia fabryk obszar ten pozostawał nieużytkowany ze względu na konieczność ponoszenia ogromnych nakładów finansowych na rekultywację gleby. Pomimo wielu propozycji zagospodarowania, dopiero po 16 latach podpisano stosowne porozumienia i zaakceptowano projekt rewitalizacji i zagospodarowania dzielnicy Bagnoli. Projekt ten obejmuje m.in budowę plaży, obiektów infrastruktury turystycznej i sportowej, obiektów mieszkalnych i uniwersyteckich, portu pozwalającego na szybkie połączenia z wyspą Nisida oraz stacji kolejowych ułatwiających komunikację. Celem artykułu jest przedstawienie możliwości rozwoju regionu Kampania, a w szczególności jego stolicy Neapolu, właśnie dzięki realizacji projektu „Bagnoli Futura”. Jest to jedno z największych przedsięwzięć, jakie w najbliższych latach zostanie zrealizowane na południu Włoch, co stworzy ogromne możliwości dla rozwoju gospodarczego nie tylko samego Neapolu, ale też dla całego regionu Kampania. Jego zakończenie przewidziano na rok 2024.

\begin{abstract}
The article presents the project of revitalisation undertaken in the post-industrial district of Naples - Bagnoli - situated strategically by the Gulf of Pozzuoli. The author focuses on the industrial development of the region, starting with its booming times during the post-war period, through the crisis of the 1970s, followed by a complete shutdown of factories in 1991. Since then, the area remained unused due to the great financial investments that would be needed to re-cultivate the land. Despite a lot of proposals to develop the land, it took 16 years to sign appropriate agreements and accept the project to revitalise the Bagnoli district. The project includes, among others, the creation of a public beach, tourism and sports infrastructure, housing estates and university campuses. It also includes building a harbour, which will enable a quick and convenient connection with the Nisida island and railway stations facilitating communication in the region. The aim of the article is to present the possibilities of development of the Campania region, focusing mainly on its capital. The 'Bagnoli Futura' project is one of the biggest ventures that will be carried out in the south of Italy in the upcoming years. It will provide great possibilities to develop not only the city of Naples itself, but the whole Campania region as well. Completion of the project is scheduled for 2024.
\end{abstract}


Słowa kluczowe: Bagnoli-Coroglio; Neapol; rewitalizacja; zagospodarowanie przestrzenne

Keywords: Bagnoli-Coroglio; Naples; revitalisation; spatial development

Otrzymano: 19 listopada 2017

Received: 19 listopada 2017

Zaakceptowano: 25 maja 2018

Accepted: 25 May 2018

\section{Sugerowana cytacja/Suggested citation:}

Noviello M. (2018). Projekt rewitalizacji dzielnicy Bagnoli jako czynnik wzrostu gospodarczego Neapolu. Przedsiębiorczość-Edukacja [Entrepreneurship-Education], 14,137-149.DOI: 10.24917/20833296.14.10

\section{Wstęp}

W polskiej literaturze z definicją rewitalizacji mierzyło się już wielu badaczy. Na początku używali oni tego pojęcia w stosunku do odnowy miast. Jest to jednak bardzo ogólne i nieprecyzyjne stwierdzenie, dlatego też dla potrzeb niniejszej pracy posłużono się definicją K. Skalskiego (2010), przywołaną w artykule A. Stefanowskiej i K. Malec (2015), gdzie rewitalizacja określana jest jako: „kompleksowy program remontów, modernizacji zabudowy i przestrzeni publicznych, rewaloryzacji zabytków na wybranym obszarze, najczęściej dawnej dzielnicy miasta, w powiązaniu z rozwojem gospodarczym i społecznym. Rewitalizacja to połączenie działań technicznych - takich jak np. remonty - z programami ożywienia gospodarczego i działaniem na rzecz rozwiązania problemów społecznych, występujących na tych obszarach: bezrobocie, przestępczość i brak równowagi demograficznej. Niewłaściwe jest więc mówienie o rewitalizacji jednego budynku, czy rewitalizacji placu miejskiego, jeżeli te działania dotyczą jedynie modernizacji budynków, czy rewaloryzacji zabytków" (Stefanowska, Malec, 2015: 6-7). Problem podjęcia działań rewitalizacyjnych był poruszany przez wielu naukowców, m.in. w odniesieniu do kwestii rewitalizacji centrum miasta - jego tkanki historycznej. Zwracano wówczas uwagę na zachowanie tożsamości miejsca w kontekście uszanowania uwarunkowań kulturowych, oczekiwań mieszkańców i ostatecznych decyzji lokalnych władz (Denis, 2016). Tematykę rewitalizacji obszarów poprzemysłowych przedstawia szeroko J. Sztaba (2013), która wskazuje na szanse rozwoju regionów poprzemysłowych po przywróceniu im pełnej funkcjonalności w wymiarze społecznym, gospodarczym i przestrzennym ${ }^{1}$. W związku z tym, iż niniejsza praca kładzie szczególny nacisk na aspekty społeczno-ekonomiczne i gospodarcze, jakie podano w przywoływanych definicjach, uważa się je za punkt wyjścia do kolejnych rozważań.

Należy zaznaczyć, że pierwsze projekty rewitalizacji przestrzeni miejskich w Europie (Szwecja, RFN, Holandia) miały na celu poprawę stanu technicznego obiektów, a nie rozwiązywanie problemów społecznych i gospodarczych (Stefanowska, Malec, 2015). Jednak, jak pokazały doświadczenia z wielu miejsc w Europie (np. Liverpoolu, Genui, Mediolanu) i na świecie (np. Rio de Janeiro, Nowego Jorku), inwestycje np. w stare, zdegradowane i opuszczone obiekty poprzemysłowe dają szansę na stworzenie nowego obrazu tej części miasta przez zachowanie jej historii i tradycji. Zachowanie pewnego fragmentu historii

${ }^{1}$ Autorka w swojej pracy dokonuje systematyzacji pojęć rewitalizacji, rekultywacji, remediacji, rewaloryzacji i renowacji. Więcej w: Sztaba (2013). 
miasta dzięki decyzji o ponownym wykorzystaniu obiektów (stanowiących część zdegradowanej dzielnicy), które mogłyby się wydawać nieużyteczne lub wręcz szpecące, przyczynia się do zacieśnienia więzi mieszkańców z tymi miejscami, gdyż przywykli oni do ich obecności lub są wręcz z nimi związani w sposób bezpośredni (byłe miejsca pracy). Jest to niezwykle istotne ze względów społecznych, gdyż sentyment do określonych miejsc powoduje chęć powrotu do nich lub przeciwdziała emigracji z miejsc, które mogłyby wydawać się skazane na zapomnienie. Dlatego też w momencie rozpoczęcia przez władze lokalne projektu rewitalizacji danego obszaru, kluczową rolę odgrywają jej bezpośredni konsumenci, czyli mieszkańcy danego miasta lub dzielnicy. W polskiej literaturze zwraca się również dużą uwagę na to, aby działania rewitalizacyjne współdziałały ze strategią rozwoju miasta i kierunkami zagospodarowania przestrzennego. Sukces rewitalizacji obejmuje również działania monitorujące cały przebieg procesu, za co odpowiedzialne są głównie samorządy miejskie (Stefanowska, Malec, 2015). We włoskich realiach taką funkcję pełni Program rewitalizacji i zrównoważonego rozwoju dla obszarów miejskich (wł. Programma di Riqualificazione Urbana e Sviluppo Sostenibile del Territorio P.R.U.S.S.T.). Został on ustanowiony przez Rozporzadzenie Ministra nr 1169 z 8 października 1998 roku i promowany przez ministra pracy. Celem tego programu jest realizacja zadań polegających na rozszerzeniu i modernizacji infrastruktury na płaszczyźnie ekonomicznej i produktywnej oraz walka z bezrobociem (aspekt społeczny) przez ożywienie gospodarcze i rewitalizację obszarów miejskich. Program służy również realizacji zintegrowanego systemu działań dla ekspansji przemysłu, handlu i promocji turystyki na obszarach peryferyjnych, poprzemysłowych, będących w fazie degradacji (Isfort, 2014). Poruszając kwestie rewitalizacji, nie można pominąć istotnego czynnika ekonomicznego, który jest de facto najistotniejszy z punktu widzenia rozwoju miasta. Można poprawiać jakość życia w mieście, czynić je ładniejszym, ale mieszkańcy potrzebują konkretnych impulsów, aby dostrzec w zdegradowanej części miasta potencjał ekonomiczny. Warunkiem skuteczności rewitalizacji danego obszaru jest to, aby podjęte działania miały konkretne założenia, takie jak:

- ożywienie społeczno-gospodarcze regionu,

- przywrócenie nieruchomościom ich utraconej wartości,

- uzyskanie ładu przestrzennego,

- poprawa estetyki oraz wizerunku regionu, a także tożsamości lokalnej mieszkańców,

- współpraca między różnymi podmiotami,

- partycypacja społeczna, włączenie mieszkańców do procesów decyzyjnych,

- wsparcie konsultingowe i formalne społecznych grup inicjatywnych,

- poprawa standardu zasobów mieszkaniowych,

- wzrost liczb przedsięwzięć w obszarze realizacji inwestycji,

- zwiększenie udziału społeczności lokalnej w życiu kulturalnym (Sztaba, 2013).

Jest to duże wyzwanie dla władz lokalnych, które w zależności od skali projektu powinny być wspierane przez władze wyższego rzędu, aby sprawnie i efektywnie przeprowadzić proces rewitalizacji.

\section{Cel opracowania}

Rewitalizacja obszarów poprzemysłowych jest ogromną szansą dla miast, zwłaszcza tych, które nie w pełni wykorzystują swój potencjał turystyczny. Dotyczy to również tych miast, które dotychczas borykały się z problemami pogłębiającego się bezrobocia i związanego 
z nim odpływu ludności oraz charakteryzują się ogólną, niekorzystną koniunkturą gospodarczą. Przykładem takiego miasta jest Neapol, leżący w południowej części Włoch, w regionie Kampania, nad Zatokami Neapolitańską i Pozzuoli. Głównym celem artykułu jest przedstawienie i ocena projektu rewitalizacji poprzemysłowej dzielnicy Neapolu Bagnoli-Coroglio w kontekście jego efektywności z punktu widzenia dalszego rozwoju turystyki wypoczynkowo-rekreacyjnej w tym regionie. Autorka zwraca uwagę na strategiczne położenie obszaru inwestycji między malowniczym wzgórzem Posillipo a Polami Flegrejskimi w kontekście możliwości poszerzenia oferty turystycznej regionu o aktywne spędzanie czasu i zwiedzanie pobliskich stanowisk archeologicznych (Pompeje, Herkulanum, Pola Flegrejskie, Cuma, Termy Agnano). Autorka publikacji przedstawiła również przesłanki (pośrednie i bezpośrednie), którymi się kierowano, decydując się na realizację tego projektu. Poza panoramicznym przedstawieniem faz projektu autorka zwraca również uwagę na problemy w jego przeprowadzeniu (ograniczenia i punkty krytyczne, zarówno na lądzie, jak i na obszarze morskim), którym muszą sprostać władze lokalne, aby w pełni zrealizować to przedsięwzięcie.

Realizacja tego, jak dotąd największego w skali Włoch, projektu rewitalizacji obszaru poprzemysłowego będzie wielkim wyzwaniem na skalę lokalną, regionalną i krajową. Stworzy to jednak możliwość walki ze stereotypami, problemami społecznymi i ekonomicznymi tego regionu oraz będzie szansą na promocję miasta w Europie i na świecie.

\section{Rewitalizacja jako możliwość rozwoju turystyki miast}

Znaczenie turystyki w rozwoju gospodarki światowej ciągle wzrasta, stąd też miasta konkurują ze sobą i poszukują nowych możliwości przyciągnięcia turystów. Starają się również tak skonstruować swoją ofertę, aby była ona skierowana do jak najszerszego grona potencjalnych konsumentów. W związku z tym, iż przestrzeń miejska jest ograniczona i daje pewnego rodzaju limit powierzchni, sposób jej zagospodarowania jest bardzo istotny (Parysek, 2006). Tendencje, które miały miejsce pod koniec XIX i na początku XX w. w wielu włoskich miastach wskazują, że ogromne znaczenie dla ich rozwoju miał przemysł (Genua, Mediolan, Turyn, Como, Venezia). Motorem napędowym był głównie przemysł hutniczy, zaś w miastach portowych - przemysł stoczniowy. Przykładem miasta, które wyjście z kryzysu początku minionego stulecia zawdzięcza tym właśnie gałęziom gospodarki, jest Neapol. Miasto to borykało się z ogromnym bezrobociem i masową emigracją ludności, głównie do Ameryki Północnej i Południowej oraz północnej części Europy. Powstałe w 1910 r. zakłady huty stali Ilva/Italsider² dały początek długiej, prawie stuletniej historii hutnictwa w tym mieście. Wybór lokalizacji do dziś nie został wytłumaczony (nie ma w literaturze jasno przedstawionej przyczyny wyboru tego miejsca), gdyż dzielnica Bagnoli, w której powstał cały kompleks, była już wtedy określana jako potencjalny biegun turystyki na skalę miedzynarodową, a wykorzystanie jej pod budowę obiektów przemysłowych było w tamtejszych czasach dalekie od tych zamiarów. Jedynym wytłumaczeniem jest narzucony, bardzo silny i skuteczny plan ze strony państwa, który dotyczył industrializacji południowej części kraju.

${ }^{2}$ Huta stali w dzielnicy Bagnoli nosiła początkowo nazwę Ilva, która pochodziła od łacińskiej nazwy włoskiej wyspy Elba, gdzie notuje się początki hutnictwa we Włoszech. Nazwa zakładów zmieniła się w 1964 r. na Italsider, od połączenia słów Italia i sidelurgia, czyli przemysł hutniczy. Zakłady powróciły jednak do swojej pierwotnej nazwy Ilva już w $1985 \mathrm{r}$. 
Wiele portów morskich przechodziło proces kompleksowej rewitalizacji. Przykładem w Europie mogą być porty w Londynie, Rotterdamie, Barcelonie, Genui, Antwerpii, Amsterdamie, Manchesterze czy Liverpoolu, zaś na świecie porty w Nowym Yorku, Toronto, Bostonie, Baltimor ${ }^{3}$ czy Argentynie. Dziś miejsca te stają się swego rodzaju bramą do miasta od strony wodnej i dają bardzo duże możliwości dla rozwoju turystyki (Tota, Zapart, 2012). Jak wskazują badania, procesy rozwoju i kształtowania się miast portowych ukazują ogromne znaczenie przestrzeni waterfrontu, czyli terenów poportowych i poprzemysłowych. Ten ogólnoświatowy fenomen transformacji frontów wodnych miast świadczy o zdolności adaptowania się miast do nowych sytuacji w światowej ekonomii oraz wpływa na ich zdolności oraz potencjał rozwojowy. Nowe oblicza starych miast przyciągają bowiem zainteresowanych inwestorów i turystów (Lorens, 2013), a rewitalizacja obszarów w bezpośrednim sąsiedztwie wody staje się jednym z najciekawszych przykładów odnowy i przemiany funkcji tych części miast z przemysłowej na typowo usługową (turystyka). Takie rozwiązanie zaproponowano również w innych nadmorskich miastach włoskich. Przykładem jest miasto Bari i rewitalizacja dzielnicy San Girolamo-Fesca, gdzie szczegółowo przedstawiono zdegradowaną dzielnicę nadmorską jako największy potencjał turystyczny miasta. Borykano się tam z problemem braku łączności miasta z morzem, brakiem jednolitego projektu zabudowy rezydencjalnej, co znacznie zaburzało estetykę tej nadmorskiej dzielnicy, oraz dużą degradacją przyrody. Projekt obejmuje m.in. budowę akwarium, molo oraz placu centralnego, który będzie punktem odniesienia dla rozwoju usług w zakresie turystyki w obrębie dzielnicy (Comune di Bari, 2015).

\section{Projekty i propozycje turystycznego zagospodarowania dzielnicy Bagnoli-Coroglio}

Pierwsza wzmianka o możliwości turystycznego zagospodarowania dzielnicy Bagnoli-Coroglio pojawiła się w 1872 r. Została ona przedstawiona przez włoskiego architekta i urbanistę Lamonta Younga, który zaproponował połączenie południowo-wschodniej dzielnicy św. Łucji (wł. Santa Lucia) z obszarem Pól Flegrejskich (wł. Campi Flegrei) leżących wzdłuż linii brzegowej na północnym-zachodzie miasta. Young, wykorzystując nadmorskie położenie i sprzyjającą, malowniczą orografię terenu, zaproponował w swoim projekcie, aby obie dzielnice połączyć za pomocą systemu kanałów, galerii, ogrodów i budynków mieszkalnych (wł. ville) w dzielnicę nazwaną w jego projekcie Małą Wenecją (wł. Piccola Venezia).

To niezwykle odważne, jak na ówczesne czasy, rozwiązanie nie znalazło jednak zwolenników, a sam projekt został oceniony jako zbyt innowacyjny (Cirillo, Bertoli, Scarpa, 2016). Pojawił się również problem z możliwością jego sfinansowania. Mapy z pierwszej połowy XIX w. nie wskazują, aby na terenie badań istniały jakiekolwiek zabudowania. Dopiero pod koniec tego wieku, na terenie dzisiejszego obszaru Bagnoli-Coroglio, Markiz Candido Giusso wybudował kilkanaście letniskowych obiektów mieszkalnych i termalnych (Cirillo i in., 2016), widząc w tej dzielnicy miasta ogromny potencjał turystyczny. Obiekty te nie przetrwały jednak do dzisiejszych czasów. Z względu na trudną

\footnotetext{
${ }^{3}$ Więcej na ten temat w publikacji P. Lorensa (2013), w której autor omawia szczegółowo fazy rozwoju miast portowych, typologię ich przestrzeni oraz współczesne tendencje w rozwijaniu się relacji miasto - port. W publikacji znajduje się również bogata analiza porównawcza współczesnych procesów przekształceń frontów wodnych w miastach portowych, gdzie autor przybliża kilka przykładów miast zachodnioeuropejskich i północno amerykańskich oraz porównuje je pod kątem ich struktur przestrzennych i strategii przekształceń.
} 
sytuację gospodarczą miasta i całego regionu, kilkadziesiąt lat później, w 1910 r., doszło do podjęcia decyzji o ulokowaniu w Bagnoli-Coroglio piątej co do wielkości (pod względem produkcji) huty stali we Włoszech. Hutnictwo stali było wówczas jedynym poważnym motorem napędzającym gospodarkę miast, dającym możliwość zatrudnienia bardzo dużej grupy robotniczej.

Bogata historia zakładów, przesłanki upadłości i ich ostateczne zamknięcie w $1991 \mathrm{r}$. (ryc. 1) stworzyły możliwość powrotu do propozycji turystycznego zagospodarowania tego obszaru. Już w 1990 r. Renzo Piano, obecnie najbardziej ceniony włoski architekt, przedstawił projekt „Napoli 2000”, który polegał na odbudowie wybrzeża Bagnoli, budowie portu turystycznego i dwóch parków technologicznych. Projekt ten został jednak odrzucony i w bardzo podobnej wersji przedstawiony cztery lata później przez doradcę komunalnego De Lucia. Przewidywał on stworzenie z dzielnicy Bagnoli ośrodka turystycznego, w którym 2/3 wybrzeża miała stanowić plaża, a cały kompleks miałby pełnić funkcję turystyczną, naukowo-badawczą i mieszkalną. Projekt De Lucia, zachowujący nazwę zaproponowaną przez Renzo Piano, wstępnie zaakceptowano, jednak nie przystąpiono do jego realizacji. W latach 1996-1998 dokonano w nim zmian polegających na stworzeniu kompleksu parku publicznego o powierzchni ok. 120 ha, z czego 36 ha przeznaczono pod zaplecze sportowe (wł. Parco dello Sport). Zaproponowano również zagospodarowanie plaży na tzw. lido ${ }^{4}$ oferujące 700 miejsc, wybudowanie centrum produkcji telewizyjnej, zakładów rękodzieła artystycznego (wł. manufattura) oraz bieguna kongresowego na 2000 miejsc. Nie było wówczas wzmianki o możliwości wykorzystania niektórych budynków poprzemysłowych jako obiektów archeologii przemysłowej. Pomysł taki pojawił się przy kolejnej modyfikacji projektu, która miała miejsce w latach 2000-2005, kiedy to obok decyzji o tym, które z obiektów zostaną odnowione i uzyskają nowe przeznaczenie, zaproponowano również podział całego obszaru projektu na dziewięć stref tematycznych (ryc. 2).

Pomimo licznych propozycji turystycznego zagospodarowania dzielnicy Bagnoli-Coroglio do lipca 2017 r. żaden z wymienionych projektów nie został sfinalizowany. Przeszkodą były przede wszystkim problemy ze zdobyciem środków finansowych na jego realizację, niezgodność rządzących partii politycznych w sprawie propozycji projektów oraz drastyczny wzrost kosztów realizacji, chociażby z powodu konieczności przeprowadzenia rekultywacji gleb i likwidacji przyczyn zanieczyszczenia wód.

Współczesne przemiany funkcji miejskich z przemysłowych na usługowe niosą ze sobą ogromne zmiany w krajobrazie miasta. Jest to szczególnie zauważalne w sytuacji, gdy procesowi restrukturyzacji w regionach przemysłowych, w których podejmowano decyzje o transformacji zakładów pracy, towarzyszy ich likwidacjia w wyniku niskiej rentowności lub wyczerpania pokładów złóż, a zakłady te stanowiły przez dziesięciolecia główne źródło utrzymania dla społeczeństw lokalnych i regionów (Sztaba, 2013). W krajobrazie tej części miasta często pozostają liczne nasypy, hałdy, zwałowiska oraz pojawia się tam poważny problem skażenia gleby i wód. Zanieczyszczenie to stanowi największy, bo w wielu przypadkach najbardziej kosztowny element rekultywacji obszaru postindustrialnego, przez kosztowne procesy remediacji gleb i gruntów metodami technicznymi typu

\footnotetext{
${ }^{4}$ Lido to prywatny obiekt infrastruktury turystycznej na plaży, w którego skład wchodzić mogą bar, restauracja, wypożyczalnia leżaków plażowych, łódek oraz szereg innych usług rekreacyjnych. Oferta zależy od możliwości inwestycyjnych właściciela tej struktury.
} 
Ryc. 1. Współczesny wygląd dzielnicy Bagnoli-Coroglio

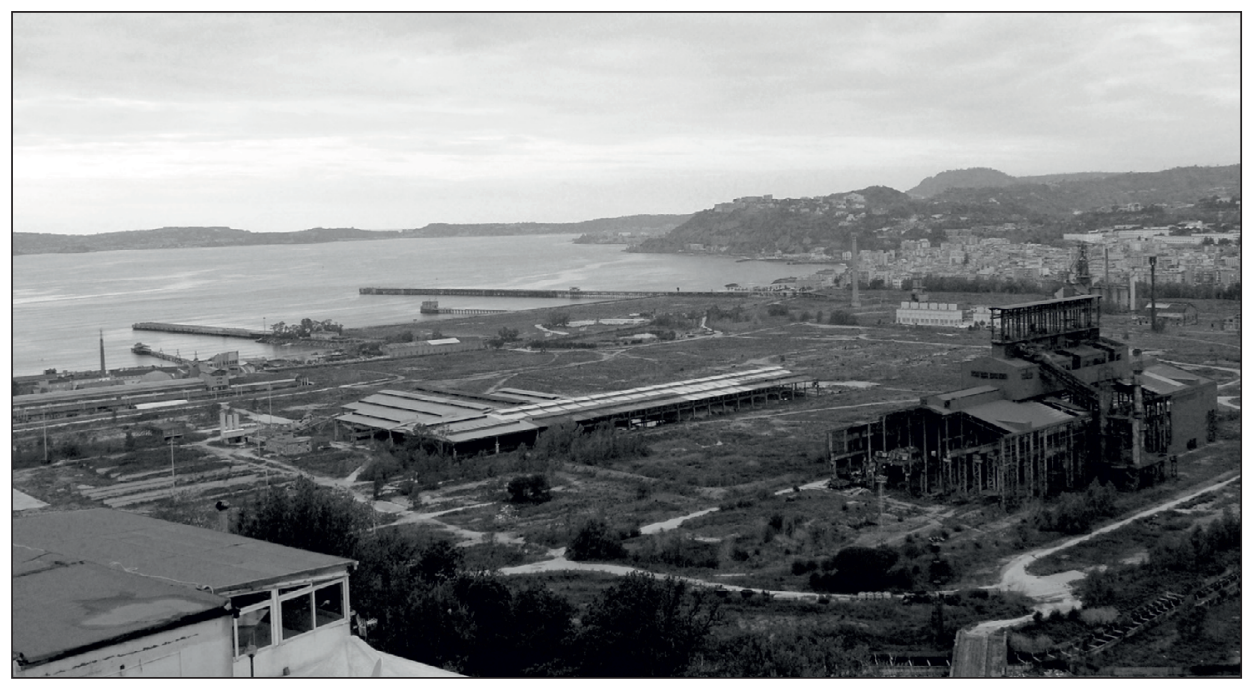

Źródło: zbiory własne

Ryc. 2. Obszar projekt Bagnoli-Coroglio z wydzielonymi strefami tematycznymi

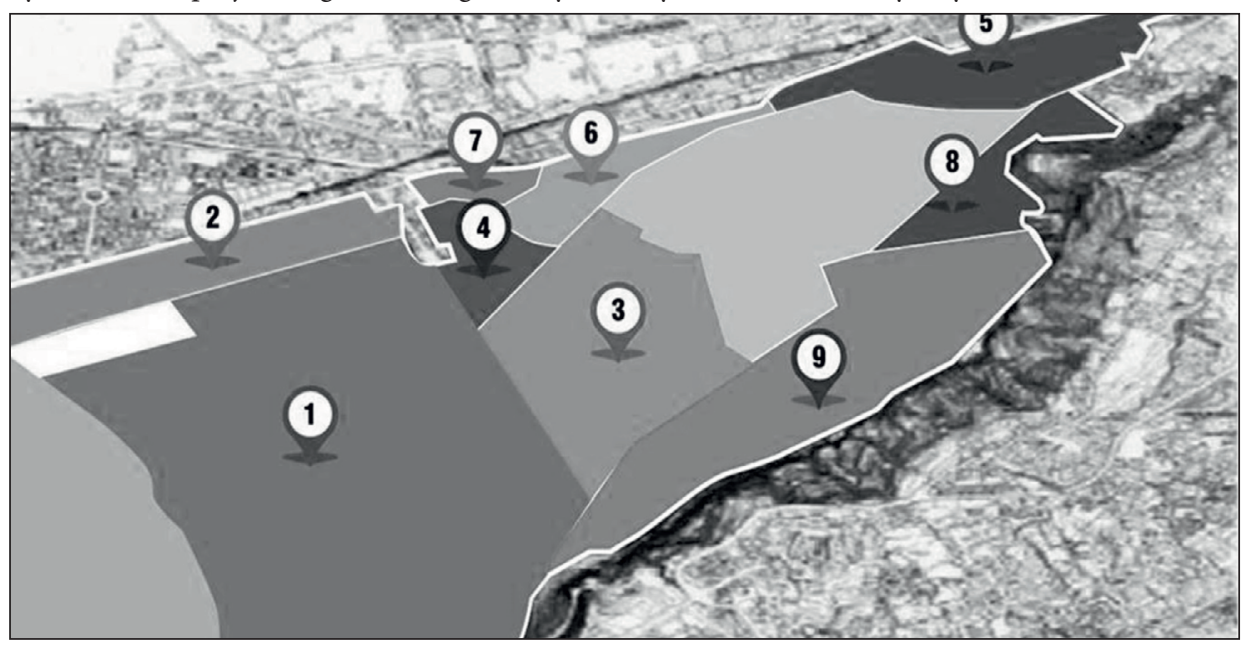

1. park i plaża; 2. wioska rybacka, obiekty noclegowe i komercyjne; 3. rezydencje, kampus uniwersytecki; 4. badania; 5. centrum handlowe, nowa stacja Cumana*; 6. usługi i produkcja; 7. mieszkania istniejące; 8. struktury edukacyjne; 9. park sportowy

Źródło: www.comune.napoli.it

${ }^{*}$ La Cumana to rodzaj metra w Neapolu, istniejącego od 1883 r., w którym większość trasy przebiega na powierzchni ziemi. Tylko początkowy odcinek znajduje się w tunelu łączącym stację Montesanto z Fuorigrotta. Linia Cumana łączy centrum antyczne Neapolu (stacja Montesanto) z miastem Pozzuoli (stacja Torregaveta) i obsługuje pasażerów wzdłuż linii brzegowej Zatoki Neapoletańskiej, dlatego stanowi jedno z ważniejszych połączeń komunikacyjnych miasta z jego prowincją. Jej długość wynosi prawie $20 \mathrm{~km}$. Zob.: http://www.eavsrl. it/web/sepsa. 
ekstrakcja pary wodnej, przemywanie gleby i elektrokinetyczne usuwanie metali. Stosowane są również metody biologiczne, takie jak: fitoekstrakcja (niezbędna przy eliminacji metali ciężkich typu ołów) czy fitodegradacja, dzięki którym dokonuje się oczyszczenia gruntów i zagospodarowania na nowo terenów poprzemysłowych, a także licznych obiektów budowlanych o różnym niegdyś przeznaczeniu. Te techniki i liczne procesy mechaniczne kreują nową postać, nowy kształt i infrastrukturę, nowe przeznaczenie terenu lub obiektu. Jak już wspomniano, tego typu działania są bardzo kosztowne, nie mogą być prowadzone dorywczo, lecz z dużym wyprzedzeniem czasowym. Muszą być też zaplanowane i realizowane przez profesjonalistów (Sztaba, 2013). Przed takim wyzwaniem stanęły nie tylko lokalne władze miasta Neapolu, przygotowujące się obecnie do długooczekiwanej realizacji projektu rewitalizacji dzielnicy Bagnoli-Coroglio - ze względu na konieczność ogromnych nakładów finansowych projekt przybrał skalę narodową.

Dokonując analizy potrzeby realizacji tego projektu, zwrócono szczególną uwagę na przesłanki, które towarzyszyły tym decyzjom. Dla jasnego przedstawienia tej części zagadnienia przesłanki te podzielono na pośrednie i bezpośrednie. Przesłanki pośrednie rozumiane są tutaj jako te, które wskazują mankamenty w skali miasta lub regionu, a realizacja projektu może wpłynąć na zmniejszenie skali ich negatywnego oddziaływania. Spośród najbardziej istotnych (w odniesieniu do projektu rewitalizacji Bagnoli-Coroglio) przesłanek wyróżnia się: a) niedostateczną infrastrukturę transportową w obrębie miasta i regionu, b) brak dostatecznej liczby szerokich, dobrze wyposażonych plaż pomimo nadmorskiego położenia miasta (istniejące plaże są zazwyczaj wąskie, kamieniste, trudnodostępne, prywatne lub bardzo drogie), c) problem z czystością wód - według Regionalnej Agencji Ochrony Przyrody Regionu Kampania - ARPAC (wł. Agenzia Regionale Protezione Ambiente Campania) w 2017 r. aż 23 km plaży w granicach miasta nie spełniało norm kąpielisk ze względu na jakość wody (ARPAC, 2017), d) potrzebę zwiększenia oferty turystycznej, co może wpłynąć na konkurencyjność regionu w skali kraju, e) wysoką stopę bezrobocia, zwłaszcza wśród osób do 35 roku życia, f) odpływ ludzi młodych - problem emigracji regionalnej i zagranicznej, g) potrzebę poprawy renomy regionu przez napływ i realizację konkretnych projektów, co daje możliwość realizacji w przyszłości nowych inwestycji na południu Włoch. Neapol, miasto portowe założone w VIII w. p.n.e., obecnie boryka się z problemem zagospodarowania przestrzeni nie tylko mieszkalnych, ale przede wszystkim tych o szerokiej funkcji usługowej. Jest to związane głównie z dostosowaniem współczesnej infrastruktuty i architektury do bardzo bogatego historycznego tła miasta. Istotne jest również, iż obszar metropolii jest zamieszkiwany przez ponad 3117 tys. osób ${ }^{5}$, a obsługuje zapewne znacznie większą liczbę ludności (dojazdy do pracy, tymczasowy pobyt, edukacja, wakacje itd.). $\mathrm{Z}$ tego względu tak bardzo ważne dla miasta są inwestycje w poprawę jego atrakcyjności turystycznej i w związku z poważnym problemem bezrobocia, głównie wśród młodych osób ${ }^{6}$, priorytetem dla miasta i całego regionu jest stworzenie nowych miejsc pracy. Kluczowe jest przede wszystkim stworzenie bogatej i atrakcyjnej oferty turystycznej skierowanej do mieszkańców regionu oraz turystów przybywających spoza jego granic.

Przesłanki bezpośrednie ku realizacji projektu Bagnoli-Coroglio rozumiane są jako te, które dotyczą samego obszaru projektu, czyli terenów byłych zakładów produkcji stali

\footnotetext{
${ }^{5}$ Dane szacunkowe pozyskane w dniu 10 października ze strony włoskiego Instytutu Statystyki (wł. Istat), www.dati.istat.it

${ }^{6}$ Jak podaje Istat, bezrobocie w regionie Kampania w 2017 r. wynosiło 20,4\%, zaś wśród młodzieży do 24 roku życia przekraczało 50\%, www.dati.istat.it
} 
Ilva/Italsider. Do przesłanek tych można zaliczyć: a) możliwość rozwoju turystyki kąpieliskowo-wypoczynkowej na bardzo rozległych obszarach poprzemysłowych leżących nad samą Zatoką Pozzuoli, b) konieczność interwencji i usunięcia zanieczyszczeń gleby i wód powstałych w procesie produkcji, a obecnie składowanych w postaci hałd i nasypów wzdłuż linii brzegowej, c) możliwość konserwacji i wykorzystania obiektów archeologii przemysłowej w celu organizowania koncertów, spektakli, spotkań kulturalnych, warsztatów i in., d) waloryzację już obecnej infrastruktury turystyczno-naukowo-konferencyjnej na terenie byłych zakładów i w ich bezpośrednim sąsiedztwie, takich jak Muzeum Morza (wł. Museo del Mare), Miasto Nauki (wł. Città della Scienza), Wystawa D’Oltremare (wł. Mostra D’Oltremare), e) sprzyjającą turystyce orografię terenu - teren byłych zakładów jest płaski, posiada piaszczyste plaże, otoczony jest malowniczymi wzgórzami Posillipo na południowym-wschodzie i Polami Flegrejskimi (wł. Campi Flegrei) na północnym-zachodzie (Comune di Napoli, 2017a). Taka lokalizacja inwestycji daje ogromne możliwości rozwoju dla całego regionu (dobrze rozwinięta komunikacja regionalna tego fragmentu miasta - stacje kolei regionalnej - Campi Flegrei i lokalnej linii metra ze stacjami Bagnoli, Cavallegeri D’Aosta, Zoo Edelandia, Mostra D’Oltremare).

W lipcu 2017 r. rząd włoski, w porozumieniu z regionem Kampania i miastem Neapol, podpisał projekt zagospodarowania dzielnicy Bagnoli-Coroglio (ryc. 2). Realizacja projektu rozpoczęła się niebawem po jego podpisaniu, a jego zakończenie przewidziano na 2024 r. Ze względu na złożoność problemu rewitalizacji tego obszaru projekt został podzielony na kilka faz, które obejmą:

- rekultywację gleb, która będzie się odbywała w kilku etapach,

- określenie nowego przeznaczenia nieużytków i kolejnego etapu rekultywacji,

- kąpieliska i sieć wodną,

- system transportu,

- wymiarowanie obszaru urbanizacji.

W ramach tego projektu przewidziano:

- budowę portu turystycznego na wyspie Nisida,

- budowę plaży publicznej (o długości 2 km, szerokości minimalnej 60 m i maksymalnej $120 \mathrm{~m}$ ) i dwóch plaż prywatnych,

- wykonanie badań w kierunku instalacji depuratorów wody i ich późniejszą realizację,

- organizację gospodarki wodnej - gromadzenie i wykorzystanie wód deszczowych,

- relokację Miasta Nauki i budowę parkingu wyposażonego w system paneli słonecznych,

- budowę Centrum Przygotowań do Olimpiad Żeglarskich,

- budowę Miglio Azzurro - centrum badań naukowych rozwiązań innowacyjnych dla zrównoważonego rozwoju,

- zmianę funkcji istniejącej zabudowy (Porta del Parco, Parco dello Sport, Turtle Point),

- budowę podziemnych stacji kolejowych (dwa państwowe, dwa lokalne - linia 6),

- budowę zaplecza turystycznego i handlowo-usługowego (hotele, restauracje, kawiarnie, sklepy itp.),

- waloryzację obiektów architektury przemysłowej - molo północne, byłe archiwum Ilva,

- budowę Placu Archeologii i zwiększenie powierzchni obiektu huty stali o 46 tys. $\mathrm{m}^{3}$ - cele kulturalne (koncerty, wielkie imprezy muzyczno-teatralne), do powierzchni 70 tys. $\mathrm{m}^{2}$, 
- utworzenie parku miejskiego o powierzchni 120 ha, 7 km ścieżek pieszo-rowerowych i edukacyjnych,

- rewitalizację miasta - odbudowę dzielnicy Coroglio (tylko budynków mających pozwolenie na budowę),

- utworzenie trzech obszarów zabudowanych obiektami użytkowymi o objętości $1790000 \mathrm{~m}^{3}$, z czego $250000 \mathrm{~m}^{3}$ stanowić będzie zabudowa mieszkalna (Fedele, Luccio, 2010; Comune di Napoli, 2017a).

W realizacji tego projektu należy zwrócić również uwagę na ograniczenia i punkty krytyczne, które mogą wpływąć na czas jego wykonania. Ze względu na bardzo duży obszar inwestycji (120 ha powierzchni) i brak dokładnych badań, chociażby stopnia zanieczyszczenia gleb w początkowej fazie projektu, trudne było określenie dokładnego czasu realizacji niektórych faz. Problematyczna i sporna okazała się również kwestia wyburzenia niektórych budynków mieszkalnych wzdłuż głównej ulicy Coroglio. Podano jedynie najistotniejsze przykłady występowania punktów krytycznych zarówno na obszarze

Ryc. 3. Projekt rewitalizacji obszaru byłych zakładów Ilva/Italsider w dzielnicy Bagnoli-Coroglio

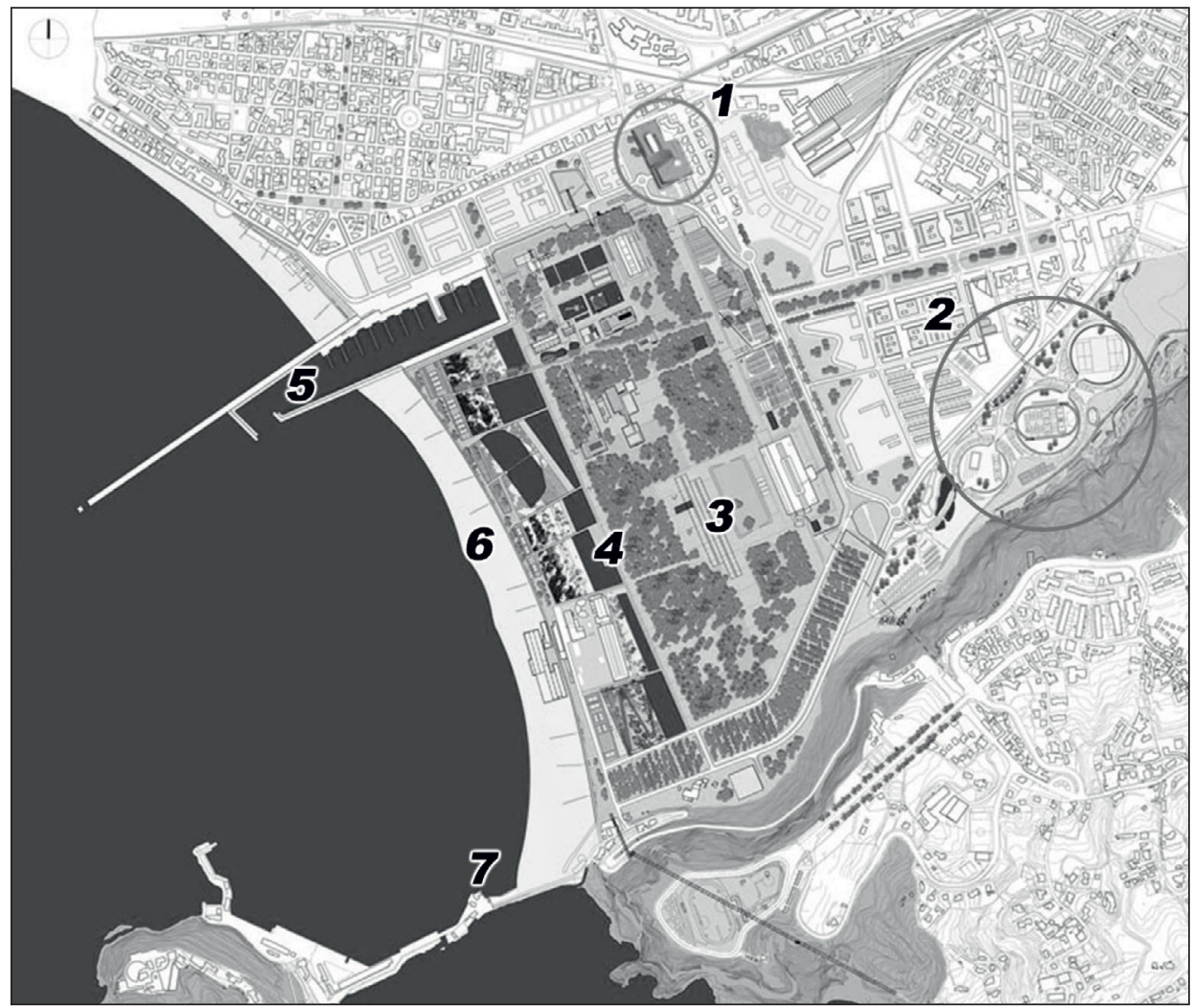

1. obiekt konferencyjny Porta del Parco; 2. obiekt sportowy Parco dello Sport; 3. park miejski; 4. deptak wzdłuż ulicy Coroglio; 5. molo; 6. plaża; 7. port

Źródło: opracowanie własne na podstawie projektu Silvio D’Ascia zamieszczonego na: www.comune.napoli.it 
lądowym, jak i na obszarze morskim, mając świadomość, że organiczeń tych może być znacznie więcej. Wśród nich wyróżniono:

- brak dokładnych informacji dotyczących wielkości zanieczyszczenia terenu i wód gruntowych - nadal przeprowadza się liczne analizy stopnia zagrożeń substancjami szkodliwymi,

- usunięcie składowisk z obiektu Eternit i określenie ich przeznaczenia,

- usunięcia odpadów poprzemysłowych składowanych wzdłuż brzegu morza (wł. colmata) i odbudowa waterfront,

- wyburzenie nielegalnego budownictwa wzdłuż ulicy Coroglio,

- usunięcie sedymentów z zatoki i odnowa środowiska wybrzeża - soil washing,

- badania transportu sedymentów, ich wielkości, badanie dynamiki wybrzeża,

- określenie systemu zrzutów wody w celu zapewnienia kąpielisk o odpowiedniej jakości,

- badania nad ograniczeniem ryzyka - wulkanicznego, sejsmicznego itp.

Propozycja realizacji projektu, a zwłaszcza jego początkowych etapów zwiazanych z rekultywacją gleb, została przedstawiona również w świetle możliwości partycypacji lokalnej społeczności w tym procesie. Jako przykład takich działań podano aktywne uczestnictwo lokalnej społeczności w projekcie utworzenia parku miejskiego na obszarze byłego lotniska Tempelhof w Berlinie. Ze względu na wielkość obszaru (powyżej 380 ha) było to wielkie wyzwanie dla lokalnej społeczności, która angażując się w rekultywację gleby, przyczyniła się do szybszej realizacji projektu (Comune di Napoli, 2017b).

Procesy rewitalizacyjne służą również ożywieniu ekonomicznemu danego obszaru. Dzięki realizacji projektów w tym zakresie podnoszony jest poziom konkurencyjności miejsca inwestycji, tworzone są nowe miejsca pracy w rozmaitych przedsiębiorstwach, a także dochodzi do rozwoju rynku nieruchomości. Kolejnym elementem jest nadanie rewitalizowanym terenom odpowiedniego image'u przez określenie charakteru przestrzeni oraz zapewnienie symboli wpisujących się w tożsamość miasta. Przykładem takich działań może być stworzenie nowych obiektów użytku publicznego istotnych z punktu widzenia przestrzeni publicznej. Kluczową funkcją rewitalizacji jest także zapewnienie swobodnego korzystania z odnowionych stref odpoczynku i rekreacji, odbywania spacerów na terenach zachęcających do tego zarówno mieszkańców, jak i turystów (Stefanowska, Malec, 2015). Partycypacja lokalnej społeczności ma bardzo duże znaczenie w procesie rewitalizacji określonej dzielnicy miasta (Kozłowski, Yusnani, 2010), gdyż może ona przyczynić się do opóźnienia realizacji projektu, jak to miało miejsce w przypadku decyzji o wyburzeniu niektórych budynków mieszkalnych wzdłuż ulicy Coroglio (Comune di Napoli, 2017b). Zaangażowanie społeczeństwa może mieć również wiele pozytywnych aspektów, począwszy od samych pomysłów na zagospodarowanie zdegradowanej przestrzeni, po aktywny udział w realizacji postawionych zamierzeń. Na znaczenie rewitalizacji w przywracaniu przestrzeni publicznej i jej roli w dalszym rozwoju miasta zwraca się uwagę w wielu publikacjach, głównie pod kątem zmian, które będą zachodziły w życiu mieszkańców (Kazimierczak, 2014; Boryczka, 2016; Sokołowicz, 2016).

\section{Podsumowanie}

Proces rewitalizacji ma bardzo istotne znaczenie dla obszaru, który obejmuje. Wskazują na to liczne przykłady projektów odbudowy centralnych i peryferyjnych przestrzeni 
miejskich, ale również tzw. waterfrontów, których zasięg oddziaływania jest znacznie szerszy. Jest to bowiem związane z tym, iż miejsca te są strategicznymi obszarami w obrębie miast, gdyż stanowią swego rodzaju bramy do nich, a także ich wizytówki. Szeroki zasięg ich oddziaływania to bardzo pozytywne zjawisko, szczególnie, gdy inwestycje są ukierunkowane stricte na rozwój turystyki jako jednej z najlepiej rozwijających się obecnie gałęzi w zakresie usług. Dlatego też decyzje o realizacji projektów rewitalizacji są niezwykle istotne dla ożywienia gospodarczego danego regionu. W przypadku omawianego projektu Bagnoli-Coroglio, którego finalnym produktem mają stać się wyposażona i wielofunkcyjna plaża, park miejski, obszar naukowo-badawczy oraz port, skala wpływu tej inwestycji na lokalny rozwój będzie bardzo duża. Neapol jest miastem borykającym się z problemem bezrobocia, emigracją, złą renomą oraz niedostateczną infrastrukturą turystyczną (Noviello M. i in., 2015). Chociaż liczba turystów odwiedzających to miasto stale rośnie, to realizacja podpisanego w 2017 r. projektu rewitalizacji poprzemysłowej nadmorskiej dzielnicy Bagnoli-Coroglio da jeszcze większe możliwości na rozwój turystyki w skali nie tylko regionalnej czy krajowej, ale też zapewne - międzynarodowej. Realizacja projektu jest więc ogromną szansą dla lokalnej społeczności, gdyż daje również możliwość napływu nowych inwestycji do Neapolu, a tym samym - stworzenia nowych miejsc pracy i przeciwdziałania bezrobociu, patologii oraz ciągle rosnącej emigracji.

\section{Literatura}

References

Agenzia Regionale Protezione Ambiente Campania (ARPAC), http://www.arpacampania.it/ Boryczka, E. (2016). Rewitalizacja miast. W:Z. Przygodzki (red.), EkoMiasto Zarządzanie. Zrównoważony, inteligentny i partycypacyjny rozwój miasta. Łódź: Wydawnictwo Uniwersytetu Łódzkiego, 168194

Cirillo, C., Bertoli, B., Scarpa, L. (2016). Napoli e il paesaggio costiero: Il recupero ambientale di Bagnoli e la rigenerazione del Litorale Flegreo. W: VI Simposio-Il monitoraggio costiero mediterraneo: problematiche e tecniche di misure. Livorno: CRN Italia, 112-118.

Comune di Bari. (2015; 2017, 10 września). Relazione progetto vincitore Concorso riqualificazione San Girolamo - Relazione progetto vincitore. Bari. Pozyskano z: www.comune.bari.it

Comune di Napoli. (2017a, 20 września). Accordo Inter istituzionale Governo Italiano, Regione Campania, Comune di Napoli. Programma di Risanamento Ambientale e Rigenerazione Urbana Area di Rilevante Interesse Nazionale Bagnoli - Coroglio. Roma. Pozyskano z: www.comune.napoli.it

Comune di Napoli. (2017b, 18 września). Un nuovo modello per la trasformazione urbana di Bagnoli. Napoli. Pozyskano z: www.acen.it

Denis, M. (2016). Rewitalizacja tkanki historycznej miast szansą na odzyskanie tożsamości miejsca. Kwartalnik Naukowy Instytutu Rozwoju Miasta, XIII(IV), 139-147.

Fedele, C., Di Luccio, A. (2010). Consenso tecnico e integrazione trasporti-territorio: il Progetto Bagnoli. Pozyskano z: http://www.tema.unina.it/index.php/tema/article/viewFile/urn\%3Anbn\%3Ait\%3Aunina-3572/198

Isfort. (2014). La riqualificazione di aeree dismesse: Un progetto di aerea vasta. Roma.

Kazimierczak, J. (2014). Kształtowanie przestrzeni publicznej centrum miasta w kontekście rewitalizacji terenów poprzemysłowych w Manchesterze, Lyonie i Łodzi. Studia Miejskie, 16, 115-128.

Kozłowski, M., Yusnani, M. Y. (2010). Rewitalizacja wybranych miast Azji, USA i Australii: możliwości wykorzystania doświadczeń dla polskich miast. Problemy Rozwoju Miast, 7(2), 50-73.

Lorens, P. (2013). Obszary poportowe - problemy rewitalizacji. Szczecin: Instytut Studiów Regionalnych. 
Noviello, M., Noviello, A., Noviello, F. (2015). Problemy rozwoju turystyki w Neapolu. W: A. Dłużewska, G. Iwanicki (red.), Geograficzne i ekonomiczne uwarunkowania rozwoju turystyki. Lublin - Krosno: Wydawnictwo ARMAGRAF, 137-146

Parysek, J. (2006). Wprowadzenie do gospodarki przestrzennej. Poznań: Wydawnictwo Naukowe UAM.

Sokołowicz, M.E. (2016). Rewitalizacja miast z perspektywy ekonomicznej. Reflekcje teoretyczne i ich konsekwencje dla praktyki planowania przedsięwzięć rewitalizacyjnych. Gospodarka w Praktyce $i$ Teorii, 4(45), 57-68.

Stefanowska, A., Malec, K. (2015). Wpływ rewitalizacji na atrakcyjność turystyczno-rekreacyjną obszaru na przykładzie Zamościa. Turystyka Kulturowa, 8, 6-19.

Sztaba, J. (2013). Rewitalizacja szansą dla regionów poprzemysłowych. Miscellanea Oeconomicae, 17(1), 109-119.

Tota, P., Zapart, A. (2012). Waterfront jako jedna z dróg rewitalizacji terenów poprzemysłowych na przykładzie projektu dzielnicy Kleczków we Wrocławiu. Architektura-Czasopismo Techniczne, 109(1), 249-259.

Monika Noviello, mgr, Uniwersytet Pedagogiczny w Krakowie, Instytut Geografii, Zakład Przedsiębiorczości i Gospodarki Przestrzennej. Absolwentka Instytutu Geografii Uniwersytetu Pedagogicznego w Krakowie (2011 r.) oraz Wydziału Architektury i Urbanistyki Uniwersytetu Federico II w Neapolu (2014 r.). Doktorantka w Instytucie Geografii Uniwersytetu Pedagogicznego, asystentka w Instytucie Geografii, w Zakładzie Przedsiębiorczości i Gospodarki Przestrzennej. Zainteresowania badawcze autorki dotyczą rozwoju regionalnego Włoch, urbanistyki i planowania przestrzeni miejskich.

Monika Noviello, MSc, Pedagogical University of Cracow, Institute of Geography, Department of Entrepreneurship and Spatial Management. She has graduated from the Pedagogical University of Cracow (2011) and the Faculty of Architecture and Urban Planning at the University of Federico II in Naples (2014). PhD student in the Institute of Geography at the Pedagogical University of Cracow, Department of Enterpreneurship and Spatial Management. Her research interests are connected to regional development of Italy and urban planning.

\section{Adres/Address:}

Uniwersytet Pedagogiczny im. Komisji Edukacji Narodowej w Krakowie Instytut Geografii Zakład Przedsiębiorczości i Gospodarki Przestrzennej

ul. Podchorążych 2

30-084 Kraków, Polska

e-mail: mnoviello@up.krakow.pl 